\title{
6
}

\section{The Good Decision-Maker or Protecting the System}

As I have shown in the previous two chapters, digging deep is the epitome of professional decision-making. Digging deep refers to the practice whereby decision-makers interrogate asylum seekers during asylum interviews in a way that is aimed at "discovering" indicators of so-called non-credibility; most notably inconsistencies. Hence, decision-makers ask as many questions in asylum interviews and/or undertake as many extra investigations until they have enough arguments for rejecting a claim or they are convinced that a story is true "after all". This practice is not only characteristic of the SEM, but of asylum administrations in the Global North in general, as many authors have shown (see Bohmer and Shuman 2008: 136; Johannesson 2017: 12; Jubany 2017: 135-137; Kelly 2012: 765).

Helen's example in Chapter 5 showed that she fears being judged by her co-workers for not digging deep enough and "lightly" granting an applicant asylum on the basis of the principle in dubio pro refugio ("when in doubt, for the refugee"), which means that if decision-makers do not know whether an applicant's claims "are" credible or not they should decide in favour of the applicant. Helen does not want to be seen as taking decisions in an unprofessional way. Taking positive decisions is not per se an unprofessional and "bad" thing to do. To the contrary, it is an essential part of why decision-makers do the job-and why they like doing it. However, as the following statement by SEM official Denise further exemplifies, in order to take positive decisions with a "clear conscience", digging deep is a necessity:

Sometimes you do an additional interview when technically everything indicates that a story could be true but there are two, three contradictions in it. In 
such cases it just feels strange to grant asylum when there are still some uncertainties, some open questions. So, then you do [an additional interview] so that if you then get an answer that really satisfies you, you can write a positive decision with a clear conscience. ${ }^{1}$

In theory, the principle of in dubio pro refugio would allow Helen and Denise to grant the applicants asylum without digging deep. Yet, they feel uncomfortable doing so. Furthermore, from Denise's statement we can deduce a kind of moral obligation she feels to dig deep. Her professional conscience requires it. But why, and where does this moral "obligation" come from? These are the questions I pose in this chapter.

I argue that the professional values that guide decision-makers' work-and that are, as Helen's and Denise's examples show, incorporated by the caseworkers, forming a "personal" sense of what it means for them to morally do the right thing-are shaped by decision-makers' understanding of what their duty and that of the office as a whole consist of. Bureaucracies operate in ideological environments and they develop their own ideologies (see Downs 1967: 243-244). Hence, as Julia Eckert argues, "ideological projects" always underpin and are "translated and produced in administrative practice" (2020: 9). This chapter explores the ideological environment underlying and being produced by SEM officials' work. It analyses what it means for SEM officials to professionally fulfil their duty, perform their tasks and align themselves with the office (see Eckert 2020; Gill 2009: 215).

In this sense, the distinction Julia Eckert-drawing on Max Webermakes between ethos and ethics is helpful. According to Eckert,

[e] thos denotes the assemblage of values that underpin procedures, such as, for example, rule orientation, consistency, efficiency, efficacy, equality before the law and depersonalisation. [...] Ethics, on the other hand, concerns orientation towards "the good". In the case of bureaucratic ethics, values and norms associated with the substantive goals of a bureaucratic apparatus are geared towards ideas of a good society, a good life, welfare or justice. (2020: 11-12)

Both ethos and ethics must, therefore, be taken into account if we want to understand how administrative decision-making works. Hence, in this chapter I show not only what the procedural values associated with asylum decision-making are but, more importantly, also how they are shaped by the ethics of the office. I argue that decision-makers' understanding of what

\footnotetext{
${ }^{1}$ Denise, caseworker, headquarters, interview transcript, my own translation.
} 
their role is, shapes their understanding of how to carry it out professionally. Furthermore, since what administrative caseworkers think they should do informs their everyday practices, and their everyday practices shape and mediate the policies and laws they are charged with implementing (see, for instance, Silbey 2005: 324; Wedel et al. 2005: 34), we need to explore the ethics and ethos of the office in order to understand how asylum law and policies work.

I start this chapter with an anecdote from the field in which two SEM officials - a supervisor and his employee-discuss the rightfulness of a decision. From it I extract what the officials consider their duties as decision-makers to be, which then forms the basis from which I work out the ethics of the office. Following this, I discuss the different norms of what it means to be professional in the SEM and how these norms are connected to and influenced by the two substantial goals of the office: that of protecting the abstract, "noble" value of asylum and that of protecting Switzerland's "borders", meant here not in a territorial sense, but in terms of access to rights and goods.

\section{Negotiating "the Right" Decision: A Field Anecdote}

A decision-maker, Rebecca, and her superior, Alberto, are discussing a decision she has made. As Rebecca's superior, it is Alberto's duty to check and countersign her decisions before they are sent to the applicants. In this case, he does not agree with Rebecca's decision to grant temporary protection to a family from Iraq. I quote this excerpt from my field notes in detail because it brings to light several aspects of what Alberto and Rebecca believe professional decision-making involves.

I am sitting in Alberto's office, watching him go through his employees' decisions and case files. The documents he appraises, decisions that need his signature before they can go out, were left by his employees on a table outside his office. The first decision he picks up is for a family from Iraq. The decision-maker, Rebecca, has rejected the family's asylum claim, but has granted the family temporary protection. For my benefit, Alberto comments on the decision as he reads through it. I learn that the family came to Switzerland a couple of years ago because the husband started work with a human rights organisation. When the husband's contract ended, the family stayed on and filed for asylum.

Alberto tells me that he agrees with the negative decision. He says the family's problems do not qualify them as refugees. Then, looking at the 
internal application for temporary protection Rebecca has submitted, he says: "Ok, the kids are still quite young and they've been here for quite a while, so they haven't lived in their country of origin for a long time. But someone else might still have decided differently". He feels that it is a very "generous" decision. "I mean", he goes on, "they're an upper-class family. It wouldn't be a problem for them to be socially reintegrated. [...] They're a family, they're together, they can travel. They could go anywhere they want". Alberto is not quite sure what to do about the case, but he feels he cannot just let it pass like that. In the end, he decides to put it aside for two hours and then return to it. Quickly, he goes through the other decisions from the pile on his desk, reading through them, flicking through the case files and then countersigning them. Once he has finished with the other decisions, he turns back to the case of the Iraqi family even though the two hours have not yet passed.

Seemingly out of the blue, and slightly defensively, he says to me: "The question of nation states and whether one thinks nation states are good or not, has nothing to do with what we do here. It cannot be solved by what we do. I'm all for granting protection", he continues, "but we don't have to hand it to them on a plate" (aber man muss es den Leuten nicht nachschiessen). He explains to me that seeing so many cases over the past several years has made him stricter and less naïve. What is important to him is that whatever leaves his desk is fair. This, he explains, also means protecting the asylum system from abuse. Saying that, he grabs the Iraqi family's case file and tells me he will take the decision back to the caseworker, Rebecca, to discuss it with her. He says that she will either have to add more reasons for granting the family temporary protection or reconsider her decision. Alberto asks if I would like to join him. Slightly hesitant, but also curious, I follow him to Rebecca's office.

Alberto explains to Rebecca that he thinks this is a very opportunistic, upper-class family that does not need temporary protection. Rebecca says that she can see his point, but she worries that because the children are still quite young, their decision denying the family temporary protection might be quashed if the 'case' is taken on appeal to the Federal Administrative Court. "Also", she argues, "the wife has health problems". But Alberto does not think her problems are severe enough. He also does not think the fact that the young children have not lived in their country of origin would pose a problem in the event of an appeal, and he feels that the risk is worth taking. Together they discuss other possible "obstacles to removal", but Rebecca had already 
ruled them all out after consulting the Federfïhrung. ${ }^{2}$ The discussion ends with the following dialogue:

Alberto: "I think the decision is too generous".

Rebecca: "That's my problem. I'm too nice."

Alberto: "I'm also nice."

Rebecca: "Yes, of course". 3

Alberto and Rebecca agree that she will work on the case again and rethink her original decision. Before leaving to go back to his office Alberto asks Rebecca whether she "can live with" this new decision. Rebecca assures Alberto that she can, and that she will still be able to sleep at night. She promises that it will not take her long to change the decision.

As Alberto and I set off towards his office again, Rebecca holds me back, causing Alberto to come back too. She explains to me that this is just a normal part of the job. Sometimes, though not often, decisions are given back and one has to work on them again. She says that in this case she was probably influenced by the fact that she had interviewed the family herself and that they had come across as being very pleasant. Alberto says that he finds this understandable and that this is something that has really changed for him since he was put in charge of the subdivision and stopped doing asylum interviews himself. "I have become stricter, because I see so many cases", he explains, "but I can also see things more clearly now, from a certain distance, more objectively". 4

This ethnographic vignette could be analytically explored in several different directions. In this chapter, I limit myself to mapping out both Alberto's and Rebecca's understandings of professional decision-making. Rebecca and Alberto mention several different aspects of what they believe professional decision-making involves. From Alberto we learn that professional decision-making is fair, objective and apolitical. The latter characteristic he expresses by saying that one's personal opinion of nation states (and of the restrictions on freedom of movement and residence associated with

\footnotetext{
${ }^{2}$ Federführungen are SEM officials who hold lead positions for particular countries of origin. They are responsible for (co-)determining and monitoring the institution's decision-making practices in dealing with cases from these countries (see Chapter 4).

${ }^{3} \mathrm{I}$ argue that this short dialogue must at least in part be read as an expression of the defensive position decision-makers at times adopted towards me-and outside actors in general (see Chapter 2; see also Eule 2014: 104; Lentz 2014: 197).

${ }^{4}$ Field notes, my own translation.
} 
them) has nothing to do with their job. He also has clear ideas of what constitutes fair and objective decision-making. For him, fair decision-making relates to strictly following the law, and objective decision-making to making decisions "from a distance" and not becoming too personally involved in the case. From Rebecca, we learn that being a good and professional decision-maker means working fast, not becoming too personally involved in one's cases, and making decisions that one can personally endorse. We further infer from this anecdote that being naïve, "too generous" and "too nice" are considered to be features of unprofessional decision-making. Protection should be granted, but not too easily. In Alberto's words: "It shouldn't be handed to [asylum seekers] on a plate". In order to understand why all of this has come to define professionalism for Rebecca and Alberto, I turn to the ethics of the office to demonstrate how it can be derived from what caseworkers understand their duties as decision-makers and state officials to be.

\section{Ethics of the Office: Decision-Makers as Protectors of the System}

In "Modernity and the Holocaust", Zygmunt Bauman (1989: 159) suggests, as Tone Liodden writes, "that there is a tendency in bureaucracies to shift the sense of moral obligation from those who are affected by decisions, towards colleagues and the demands of the system" (2016: 242). In Bauman's understanding, this makes bureaucracies anethical and amoral (see also Graeber 2015; Herzfeld 1992). This shift of moral obligation that Bauman describes is important and is something I also observed in the SEM. However, I challenge his interpretation that this makes administrations anethical and amoral. Rather, following Julia Eckert (2020), I argue that ethics should be understood not in a normative, but rather in an empirical way (see also Fassin 2012: 4). In this sense, "ethics are intrinsic to bureaucracy" (Eckert 2020: 9). Decision-makers' sense of moral obligation is ethical, whoever or whatever they feel it towards.

In his study of different "asylum sector intermediaries" Nick Gill argues that "states $[\ldots]$ command powers that are capable of engendering the will to act in accordance with state objectives, rather than simply generating the necessity or imperative to do so" (2009: 215, 219, emphasis in the original). This "will to act in accordance with state objectives" was something I frequently observed. Many decision-makers I spoke to strongly identified themselves with the office and with what they perceived to be the 
state's—and, therefore, the office's_-objectives (see also Affolter et al. 2019: 273-274).

According to Max Weber's ideal-typical bureaucracy, "loyalty to the office" (Amtstreue) is a characteristic of bureaucratic rule (2013 [1978]: 705). Decision-makers in the SEM share this ideal-typical value. Thus, being loyal to the office is regarded as very important, as exemplified by a SEM official who in a conversation with Jonathan Miaz said: "I have to do what the office says, otherwise I will somehow betray the office and I don't want that either" (Affolter et al. 2019: 276). Similarly, Olga Jubany observed amongst immigration officers in the UK that "[i]n their exercise of their professional role, officers' responsibility and accountability is not directed to the asylum seekers but to the immigration service and the organisation. Officers' responsibility is almost invariably related to their feelings of professional duty" (2017: 192). This sense of duty she argues "is inextricably linked to defending the system" (ibid.: 209).

My analysis differs from that of Jubany in that I do not claim that decisionmakers feel no responsibility towards asylum seekers. They do, as I will show later on in this chapter. However, I concur with her in that decisionmakers often put their responsibility towards "the system" over responsibility towards asylum seekers (see also Poertner 2018: 288). Or, rather, I argue that responsibility towards asylum seekers is aligned with and subsumed under the responsibility to protect the system.

In the field anecdote above, we can see that for Alberto the Iraqi family does not deserve protection because, as an "upper class family", they are not sufficiently vulnerable. They do not fit the image of victims in need of help. ${ }^{5}$ "They could go anywhere they want", he claims. From this, we can deduce decision-makers' dual duty. On the one hand, decision-makers must make sure that those "really deserving of protection" receive protection. On the other hand, they must protect the system from being abused by "undeserving" applicants. This dual duty of protecting people-but only deserving peopleand filtering out the undeserving in order to protect "the system" becomes apparent in the wording the SEM uses to describe the "[b]asic principles of asylum legislation" on its website:

It is the duty of asylum proceedings to identify those asylum seekers among the new arrivals who are entitled to protection under the terms [of the Geneva Convention]. Many asylum seekers cannot be classified as refugees or persons

\footnotetext{
${ }^{5}$ Several authors have shown that asylum (and immigration) politics, law and decision-making produce a very particular "'figure' (Fassin 2007: 512) of the deserving aid recipient, framing him or her as a victim in need of protection" (Cabot 2013: 453; see also Ticktin 2006; Zetter 2007).
} 
displaced by war. On the basis of their situation, they clearly belong to the group of migrants. They are in search of a better place to live in Switzerland. Knowing that they would hardly obtain an entry or work permit, they cross the border illegally. Many of them invent a dramatic story of persecution for the hearing by the authorities. With such tactics they hope to be granted refugee status. From the viewpoint of the person concerned, this behaviour is understandable, from the perspective of asylum legislation it constitutes abuse of asylum proceedings. The authorities must reject such applications without delay and execute removal systematically, making asylum proceedings unattractive for foreigners seeking employment. ${ }^{6}$

The quote illustrates a common assumption in the SEM that many (or even most) asylum seekers will lie. While deemed understandable ("anyone in that situation would do it", I was often told), it is, nevertheless, the decisionmakers' duty to separate the "real" from the "false" refugees, the ones "telling the truth" from the ones "who are lying" (see also Bohmer and Shuman 2018: 160; Fassin and Kobelinsky 2012: 446; Kobelinsky 2015: 67). This is regarded as important because the asylum system is only seen to work if those "not deserving of protection" are denied asylum. The following quote from Jonathan Miaz's fieldwork shows this distinction nicely: "I think that saying 'no' to someone who's not a refugee in the sense of the UNHCR and of the Refugee Convention contributes to the protection of the asylum institution. One has to say 'no' to those who are not refugees in order to be able to say 'yes' to those who are" (Affolter et al. 2019: 273).

Reserving refugee protection for those "truly deserving of it", therefore, becomes a necessity for upholding the value of the asylum system. Thus, as Didier Fassin and Carolina Kobelinsky argue, "[ $\mathrm{t}$ ]he less frequently [asylum] is granted, the more precious refugee status becomes" (2012: 464). This means that in order to maintain the value of asylum, many applications need to be rejected (ibid.: 465).

Under "basic principles of asylum legislation" the SEM states on its website that it is decision-makers' duty to make "asylum proceedings unattractive for foreigners seeking employment". I argue that the ethics-understood in an empirical sense-underlying this is that Switzerland must be protected from so-called "foreigners" or "outsiders" (see Jubany 2017: 212) by making sure that not "too many foreigners" come to and are allowed to reside in Switzerland. Decision-makers thereby become "guardians of a restricted good": in this case, the right to reside in Switzerland (Heyman 2009: 381; see also Lipsky 2010: 4). As a kind of "meta-message" (Jubany 2017), this duty is

${ }^{6}$ https://perma.cc/ZG4B-NN6U, last accessed 26.02.2020. 
frequently conveyed in the SEM. This became particularly visible in the induction training, where it was not explicitly taught, but was consistently implied, as the following examples show.

In one of the training courses I attended, the instructor presented us with a graph comparing the number of new asylum applications in Europe and in Switzerland between 1998 and 2014. The graph showed that, in 2014, the percentage of asylum applicants in Switzerland was at its lowest point since 1998, dropping from 8.2 per cent in 2012 to 3.8 per cent in 2014 . Drawing attention to this, the instructor commented: "Switzerland must have done something right, since the percentage of applications has gone down like this". ${ }^{7}$ The message was quite clear. If Switzerland-through its frontline decision-makers-did its job well, this reduced the number of applications (especially in comparison with other European countries).

The second example comes from a course on how to deal with applications for family reunification. The instructor told the new decision-makers that the institutional practice for dealing with Eritrean applications was to request DNA proof that the applicants were indeed related to the people they intended to bring to Switzerland. The instructor said: "If they do not hand in DNA proof, the case is ready to be decided, namely negatively. I have seen that people have still been granted entry in such cases. Please don't do that. That's the worst signal we could be sending out". ${ }^{8}$ With this statement, the instructor urged trainees to make sure their decision-making did not send out the wrong message to avoid creating a "pull-effect". The wrong message would therefore be that Switzerland is a country where family reunification is easy.

The two substantial goals the office is geared towards can be deduced from the examples above. As a Federal institution, the SEM-and, therefore, its staff-are requested to represent "national interests". On the one hand, this means fulfilling Switzerland's duties under international law (particularly the Geneva Convention and the UN Convention on the Rights of the Child) and maintaining its self-ascribed image as a humanitarian country. Upholding the noble value of asylum succeeds by excluding those "undeserving" of it. The scarcer asylum protection becomes, the more precious its value. On the other hand, it also means securing Switzerland's "borders" by restricting noncitizens' access to rights and goods, and by making sure that there are not too many "foreigners" residing in Switzerland. My analysis subsumes both sets of practices within the phrase "protecting the system", which, via two ostensibly

\footnotetext{
${ }^{7}$ Training instructor, A-modules, field notes, my own translation.

${ }^{8}$ Training instructor, C-modules, field notes, my own translation.
} 
opposed logics, comes to mean keeping numbers of asylum applicants low. This is at least partly achieved by keeping acceptance rates low.

My point here is not to say that all decision-makers consciously strive towards keeping numbers low. Many explicitly do not. Furthermore, many decision-makers do not per se share the political view that immigration to Switzerland should be restricted. However, I argue that regardless of decision-makers' personal political views and ideologies, the ethics of the office have an impact on and implicitly shape decision-makers' understanding of what it means to do their job well. This explains how and why "digging deep" becomes subsumed under professional, objective and neutral decision-making, while "easily believing" asylum seekers is associated with lazy, naïve, sometimes even politically motivated, and, thus, unprofessional decision-making.

\section{Ethos of the Office: Professional Norms and Values}

What administrative caseworkers "think they should do shapes what they actually do as much as other constraints", Julia Eckert argues (2020: 8). Decision-makers' role perception; what they perceive their duty to consist of; what commonweal or just order they believe they must work towards; and who or what they feel loyal to are crucial in this regard (ibid.). But also, the more procedural norms and the dominant values in the office regarding how decision-makers should carry out their duty as protectors of the system and the tasks connected to this duty, shape what decision-makers do. In this part of the chapter I explore such institutional norms and values that prevail in the SEM; many of which were already brought up by Alberto and Rebecca in the field anecdote described above.

The aim is not to paint a coherent picture. Good decision-making in the SEM suggests juggling different norms and values; many of which stand in (potential) conflict to one another. Hence, good decision-makers both do justice to the individual 'case' and strictly adhere to the law and institutional practice. They are emotionally distanced from the applicants but at the same time understanding and compassionate towards them. They are "politically neutral", yet, they have a political "state-duty" to fulfil. They live up to the professional role of the sceptic, but, at the same time, they are not cynical. And they work fast, while still carrying each task out carefully in order not to create more work at a later stage. 
Each of these values is now separately explored in more detail. I analyse the meanings ascribed to them; how they structure everyday decision-making and how they are linked to the ethics of the office.

\section{The Efficient, Fast and Economical Decision-Maker}

The quality charter given to all caseworkers in the SEM's asylum directorate reflects common characteristics of what is known as New Public Management. It states that

[w]e decide who is granted protection in our country and who has no such need. We are aware of the fact that our job has major consequences for the lives of affected people. That is why our actions must meet high quality standards. [...] We treat asylum seekers in a fair and correct manner, regardless of what their claim consists of. Asylum applications are treated competently and in consistence with the law and institutional practice [...]. In doing so, we work efficiently, fast and economically. [...] We make quality measurable: we set quality targets, define binding standards and make use of the necessary measuring instruments.

New Public Management reforms were introduced in the SEM and other public administrations in Switzerland "from the early 2000s onwards" (Poertner 2018: 274). ${ }^{10}$ Typical of these reforms was, amongst other things, the introduction of explicit performance standards and measurements as well as a strong emphasis on the so-called "output" of public administrations (see Gill 2016: 39; Hood 1991; Rose 1999: 150-151).

In the SEM today, quantitative targets are regularly defined for the whole institution, each division and section as well as for every individual decisionmaker. All decision-makers, as well as the sections and divisions themselves, receive monthly statistical charts which show them what they have achieved and whether they have fulfilled their quantitative aims or not. While reaching their targets never posed a problem for a few of the decision-makers I spoke to- - some did not even know how many decisions they were supposed to take each month, it was so easy for them-the majority of my interaction partners suffered because of this time pressure and struggled, and often failed, to reach their monthly target. Hence, they work under a lot of pressure to produce

\footnotetext{
${ }^{9}$ Quality charter, training material for new employees of the SEM's asylum directorate, field documents, my own translation.

${ }^{10}$ Other asylum administrations such as the FAO in Austria (see Dahlvik 2018: 63-72); the OFPRA in France (see Probst 2012: 214-222), the BAMF in Germany (see Probst 2012: 214-222) and the UDI in Norway (see Liodden 2016: 236-242) underwent similar developments.
} 
the quantitative output expected of them (see also Fresia et al. 2013: 54-55; Liodden 2016: 237; Poertner 2018: 275).

The targets for individual decision-makers are set at meetings with their superiors at six monthly intervals. They depend on officials' working hours, their customary productivity and any other tasks they might have. At the time of my research, such targets often consisted of four to five asylum interviews a month and eighteen to twenty decisions or rather, marks on their tally list, every month. What counts as output and what does not, keeps changing. During my fieldwork, both the number of asylum interviews conducted and the number of asylum decisions sent out, counted towards caseworkers' output. However, some types of decisions, like decisions concerning family reunification, for instance, did not. Yet, it was not actually the number of decisions per se that counted, but rather the number of people asylum decisions had been taken for. Thus, if a decision-maker wrote a decision for a five-person family this yielded five marks, while a decision for a single person resulted in one (see also Poertner 2017: 15).

Output pressure is often particularly strongly felt by decision-makers working on fixed-term contracts because they are told that whether or not they will have their contract prolonged depends, amongst other things, on whether they manage to produce the output requested of them. Hence, one decision-maker, whom I have called Sebastian, told me that in the organisational division he worked in they had been told that whoever produced the least marks by the end of the year had to fear their contract not being renewed. He complained that this had led to rivalry between co-workers and to decisions being taken very hurriedly and badly. For people with an openended contract this had not been so bad, he explained, but in his unit, there were only a handful of them, the rest all held fixed-term contracts. His output was not very good, he told me, because he was at the time mainly working on 'cases' from single young men from what he called a "complicated country". But he hoped that his superior would be able to see beyond quantity and would also take into account the quality of his employees' decisions. ${ }^{11}$

Quantity and quality must be weighed against each other in everyday decision-making. Producing quantity is important because of the output targets set by the institution, but also because of the large caseloads relative to their time capacity decision-makers must deal with, which, according to Michael Lipsky is a typical characteristic of street-level bureaucracies (2010: 29). This is immediately apparent when one enters a decision-maker's office. Everywhere-in and on top of bookshelves, on the desks and on the little

\footnotetext{
${ }^{11}$ Sebastian, caseworker, headquarters, field notes, my own translation.
} 
tables which have been added and sometimes even on the floor-there are piles of case files: cases that need to be decided, cases which are still waiting for an answer from further investigations, interviews that need to be conducted, and cases that will "just have to wait" because they are not a priority.

I was often told by superiors that it was their job, for the abovementioned reasons, to make sure that their employees produced enough decisions. However, most of them, like Nora, claimed that they valued quality higher than quantity: "I have to make sure my people write decent (ordentliche) and correct decisions. And enough. And exactly in this order. You see, for me quality is more important than quantity". ${ }^{12}$ At the same time, they told meand complained about the fact-that for several of their fellow superiors, the opposite was often the case.

Pressure to produce enough output and to work efficiently is not only attributed to the office itself, but also to "politics" as the following statement by a superior from Jonathan Miaz's fieldwork illustrates: "[W]e [the SEM (officials)] have a responsibility towards the Swiss people and the tax payers to not just take correct decisions but decisions of the 'right quality'. [...] And I deliberately speak of 'the right quality' and not of 'optimal quality' because it could always be done better" (Affolter et al. 2019: 271). The "right quality" for this head of an asylum unit thereby means that the quality of the decision matters, but that the effort put into producing qualitatively good decisions "has to be measured against the quantitative demands of the office" (ibid.). This for him constitutes a political demand he is required to fulfil. The statement, therefore, shows how the superior has "internalised a certain accountability toward these imagined, generalised and blurred figures" of the "Swiss people" and "tax payers" (ibid.). Thus, the procedural norms regarding how officials should go about taking decisions are interpreted in the light of what decision-makers understand their duty to be. As my fieldwork has shown, my interaction partners, as state agents, felt that they had to act in the interest of "the state". What this means for them is illustrated by the above-quoted statement. State interests are, at least partially, perceived as what "Swiss people" - in a rather abstract sense-want.

According to the quality charter quoted above, decision-makers are not only expected to work fast, they must also work economically. Amongst other things, working economically implies taking decisions that will not likely be quashed by the Federal Administrative Court, since every decision that is rescinded and obliges decision-makers to revisit the 'case', costs time.

${ }^{12}$ Nora, head of asylum unit, headquarters, interview transcript, my own translation. 
As shown in Chapter 5, this fear of having decisions quashed may have an impact on the type of decision taken and the legal reasoning used to justify them. How the procedural norm of working economically shapes officials' everyday work can, for instance, be seen in the example of Theodor who once explained to me

that his superior had instructed him to stop always looking for material evidence in order to argue for the non-credibility of asylum claims using the criterion "contradiction to facts" (Tatsachenwidrigkeit). The superior considered this too time-consuming and had asked him to focus instead on framing his arguments along the lines of "insufficient substance", which could be done on the basis of the asylum interview minutes alone. (Affolter et al. 2019: 271)

Time should, therefore, be spent "wisely". The same also holds true for money. Hence, during induction training, the novices were instructed not to frivolously request that the authenticity of asylum seekers' documents be assessed by specialists, because this would cost the office a lot of money. Rather, the expectation was that this was only to be done if decision-makers were not otherwise able to assess the credibility of asylum claims in the ways described in Chapter 4. Furthermore, for some of my interaction partnersmostly occupying higher hierarchical positions in the SEM-money was even a concern beyond what it meant in terms of procedural costs. Hence, some officials claimed that it was important not to grant asylum and temporary protection "too easily" because if all "those people" then brought their families here that would cost Switzerland a lot of money. Yet, at the same time, as I will show below, other officials did not share and even explicitly criticised this view. Worrying about money in this sense was indicative of politically motivated decision-making which, in their eyes, was unprofessional.

\section{The Neutral, Apolitical Decision-Maker}

When Alberto, slightly defensively, brought up "the question of nation states" in the conversation introduced earlier in the chapter, and "whether one thinks nation states are good or not", he was referring to a particular political ideology that questions the fundamental idea of nation states. Even if he was sympathetic towards this idea-Alberto did not really state his opinion and left this possibility open - the message he conveyed is clear: on the job, there is no place for personal political opinions. But not only that. By saying that these problems "cannot be solved by what we do", he insinuated that 
decision-making is also apolitical. Both of these statements reflect perspectives that are common in the SEM and other public administrations (see Dahlvik 2018: 56; Johannesson 2017: 116-117; Liodden 2016: 207-209).

The apolitical norm fits with the impersonal spirit Weber depicts as an important feature of the bureaucratic ethos. He writes: "'Sine ira et studio,' without hatred or passion, and hence without affection or enthusiasm. The dominant norms are concepts of straightforward duty without regard to personal considerations. [...] This is the spirit in which the ideal official conducts his office" (2013 [1978]: 225). In contrast, the "politician's element" is "ira et studium" (Weber 1991: 95). Thus, according to Weber, politicians must have passion and fight, whereas bureaucrats should do neither. A similar opinion is widespread in the SEM: there all an official should do is to follow rules and "neutrally apply the law". This is illustrated in the following quote by SEM official Barbara:

I have a problem with "missionaries". And there are some here in the SEM. We don't have a mission here. We just have to decide upon cases. We don't have to protect Switzerland from foreigners. That is not our role. But some people here feel this way. They think that there are too many asylum seekers here. But that is not my problem. I am paid to take decisions, so I take decisions. On the other hand, there are some who proselytise on behalf of the asylum seekers. They think that everybody should be able to stay here. But that is not the case. We have the law. [...] And then there are the others who say: "If you give a temporary permit to this guy, who is only 20 , and then he stays for 30 years, that will cost Switzerland 10 million francs." Again, that is not my problem. If he fulfils the eligibility criteria he can stay. If you're not happy with it, you have to change the law. But then you have to go into politics, you shouldn't be working here. ${ }^{13}$

In her statement, Barbara is tellingly advocating for "political neutrality", which is widely recognised as an important norm within the SEM. She situates this "political neutrality" in the middle between what she identifies as two kinds of political "extremes": wanting to "protect Switzerland from foreigners" and believing that "everybody should be allowed to stay". This view was shared by all my interaction partners. While some tended to be more critical of "hardline" decision-making and others were more disturbed by their colleagues' "lenient" decisions, neutrality was always associated with this middle ground.

\footnotetext{
${ }^{13}$ Barbara, caseworker, headquarters, interview transcript, my own translation.
} 
Barbara uses the word "missionaries" to describe a role decision-makers should not take on. Missionaries pursue clear goals with their decisionmaking: they either want to enable everybody to stay, or to make sure that as few people as possible are allowed to remain in Switzerland. In contrast, for Barbara, professional decision-making has no room for ideologies and pursuit of goals other than following the law. She claims that a professional decisionmaker's only aim should be to "correctly" and "neutrally" apply the law, which is a common self-understanding and professional value in bureaucratic institutions (see Dubois 2005; Lavanchy 2013: 69; Miaz 2017b: 384).

Barbara claiming that it is not her role "to protect Switzerland from foreigners" could be read as standing in contradiction to her duty as protector of the system and what I have called the ethics of the office. However, I argue that it does not. As stated above, making sure that not "too many foreigners" come and are allowed to stay in Switzerland is only rarely stated-and perceived-by caseworkers as an explicit aim of asylum decision-making. But, at the same time, protecting the system is self-evidently accepted as being a decision-maker's duty and as such is rather unquestioningly adopted and incorporated by the officials. Protecting the system, which builds on the idea that Switzerland must be protected from "outsiders", lies at the heart of professionalism in the SEM, shaping decision-makers' understanding of what it means to do the job well. Yet, protecting the system is not perceived as an ideology, as lying outside the law. Rather, it informs what "correct" and "neutral" rule-following means. In this sense, protecting the system becomes apolitical as do the professional norms and decision-making practices, like "digging deep", that are associated with it (see also Johannesson 2017: 120 121). In the words of Cris Shore and Susan Wright, this is, therefore, how the political becomes masked "under the cloak of neutrality" (1997: 8).

\section{The Objective, Sufficiently Distanced and Emotionally Detached Decision-Maker}

Since he has seen so many cases as a superior, he is now able to "see things more clearly, from a certain distance, more objectively", Alberto explains to Rebecca and me. For him distance and objectivity are what it takes to be professional and reach good decisions. He considers Rebecca's decision to be a bad one because it is "too generous". Rebecca thinks that the fact that she was "too nice" and made "too generous" a decision might have been influenced by the family's pleasant appearance when she interviewed them. In other words, she thinks she had liked them too much. In the SEM, emotional attachment 
and personal involvement are seen as the antithesis of objective decisionmaking. For a decision to be objective, it should be based solely on the "facts" of the case: on applicants' recorded statements and all the written documents applicants have supplied or decision-makers have acquired. Distance and emotional detachment are considered crucial for achieving this (see also Dahlvik 2018: 56, 77; Liodden 2016: 243-244). In the following, I examine what SEM officials understand by distance and emotional detachment, and what measures are undertaken to create such distance in order to enable objective decision-making.

SEM officials are not allowed to interview asylum seekers they know personally. If they are assigned the case of an applicant they know, they are obliged to give it back or pass it on to a co-worker. Moreover, in a training module dealing with the role of decision-makers in the interviews, trainees were told to maintain appropriate distance-not just towards asylum seekers, but also towards other professionals who participate in asylum interviews. They were informed that whereas it was not forbidden to befriend these professionals outside work, the interview was not a place for informal or personal conversation. ${ }^{14}$

Separate waiting rooms reflect the distance created between different types of actors. At the headquarters, one waiting room is for asylum seekers, and a separate room is shared by interpreters, social aid representatives and other visitors such as myself. The minute-takers have their own keys and move around the buildings freely. At the two reception and processing centres where I conducted my fieldwork, the auxiliary personnel sit in the same common room as the decision-makers themselves, while asylum seekers wait elsewhere. This separation ensures that all personal encounters and interactions between officials and asylum seekers are confined to interviews, where they are entirely "professional". This not only secludes the decision-makers but the interpreters, minute-takers and social aid representatives are also kept apart from the asylum seekers (although they all might go outside to smoke together). Several officials told me that these separate waiting rooms enabled interpreters to keep their distance from asylum seekers because otherwise they might be approached by the latter. An asylum seeker may, for instance, ask them for help in answering questions appropriately or may ask

\footnotetext{
${ }^{14}$ In practice, this is somewhat different. Several decision-makers maintain friendly ties with minute-takers and interpreters and this was evident during interviews when they initiated personal conversations or took breaks together. However, caseworkers are always careful to maintain a certain distance between themselves and the asylum seekers. Thus, conversations between decision-makers and asylum seekers are usually limited to the interview itself and, at times, to some formal small talk on the way to and from the office and the waiting room.
} 
them to tell them what questions might be asked. I argue that SEM officials are thereby not only preoccupied with keeping interpreters and asylum seekers apart for the sake of the interpreters, but also for the sake of their own decision-making. This has to do with the moments of translation in the asylum interviews simultaneously playing a crucial role in the decisionmaking process and yet being very difficult for the decision-makers to control since they do not know what is being said between the asylum seekers and the interpreters.

Another feature that promotes professional distance is the seating arrangement during the interviews, which usually take place in an official's personal office. The offices are equipped in a standard manner. The minute-takers sit at a desk with a computer. All the other participants are placed around a larger rectangular table. These small rooms become very cramped during an interview when five participants (including me) are sitting in them. This forces people to sit close together. Although seating arrangements are generally not conscious decisions, but merely copied from other officials, most decisionmakers sit at opposite ends of the table from asylum seekers, and so it is they who sit the farthest apart. When I asked an official called Gabriel why they always sat like that he replied: "Well, for me it's important that I can look the applicant in the eye, that I can look at him during our conversation, that I'm opposite him and sometimes I am also grateful for the distance". ${ }^{15}$

Gabriel's quote points not only to the importance of distance, it also illustrates the value decision-makers ascribe to the "proximity" of face-to-face encounters. Face-to-face encounters are valued for a number of reasons. As shown in Chapter 4, they are seen as an important source of professionalpractical knowledge. Furthermore, decision-makers believe that by seeing the applicant they can do better justice to the individual case, because they get a better feeling of what is really at stake. Moreover, many decision-makers told me that it was easier to stand by their decisions if they had personally interviewed the asylum seeker. They usually felt more confident that they were making "the right" decision when this was the case (see Chapter 4). Finally, one decision-maker, Lucy, told me that she found doing asylum interviews important, because "you sit opposite these people time and again and you realise that it is not just a number [you are dealing with], but a human being with all his hopes and dreams" (see also Dahlvik 2018: 61). ${ }^{16}$ Yet, while close encounters in the interviews are acknowledged as important for the aforementioned reasons, decision-makers also see a danger that, like Rebecca, they will become emotionally attached. Hence, being a good decision-maker requires

\footnotetext{
${ }^{15}$ Gabriel, caseworker, headquarters, interview transcript, my own translation.

${ }^{16}$ Lucy, caseworker, headquarters, interview transcript, my own translation.
} 
maintaining the right balance between proximity and distance. All my interaction partners told me that, for this reason, they usually put the case file aside for a couple of days after the interview, to (re-)gain some distance, so that their decision would not be influenced by sentiments the interview might have triggered. In this way, they become objective again.

What I have described so far is the meaning given to "distance" as a professional norm by the SEM officials themselves. At the same time, in academic literature, "distance" and "distancing" are used in a more analytical and often critical way to describe bureaucratic work. Tobias Eule, for instance, uses the term to describe how people become cases, numbered files and outputs in and through administrative procedures (2014: 109; see also Fuglerud 2004: 36; Scheffer 2001). This is something I too observed in the SEM and is most clearly expressed in the language decision-makers use when talking about the people they deal with. However, in terms of institutional values, reducing people to numbers and not recognising them as individuals is regarded as doing one's job badly. Thus, in the training sessions, the new decision-makers were frequently reminded that they were dealing with "people and not numbers" or in the words of one instructor: "You decide whether someone has to go back home or not. This isn't just a piece of paper". ${ }^{17}$ The common outside critique of reducing people to numbers, cases or files is thereby mirrored in this internal value. Good decision-makers are supposed to care for the people they deal with (see also Watkins-Hayes 2009: 70). Therefore, following Veena Das, I argue that (emotional) detachment should not be equated with cold disinterest (2015: 103-106; see also Candea et al. 2015: 24).

Academics engaging critically with bureaucratic institutions have, furthermore, argued that administrative caseworkers take decisions, which lead to inhumane circumstances and may at times even prove to be lethal, because they are physically and psychologically distanced from the outcomes of their actions. Thus, they do not feel responsible for them (see Arendt 2013; Bauman 1989; Eule 2014: 109; Gill 2016). In the SEM, decision-makers are also to some extent physically and psychologically distanced from the outcomes of their decisions. Hence, on the one hand, they are very rarely present when asylum seekers learn of their decision because, especially at the headquarters, almost all decisions are sent out as letters. ${ }^{18}$ On the other hand,

\footnotetext{
${ }^{17}$ Training instructor, A-modules, field notes, my own translation.

${ }^{18}$ Theoretically, there is the possibility of passing judgement verbally. However, this is rarely done at the headquarters and then mostly for positive decisions. At the reception and processing centres it happens a bit more frequently and there mostly with negative decisions.
} 
they are not present when rejected applicants are deported since once a negative decision has been taken and becomes legally binding, the 'case' is passed on to the return division of the SEM and the responsibility for deporting this person is transferred to the canton of residence.

This was different during the three years, between 2007 and 2010, in which Federal Councillor Eveline Widmer-Schlumpf was in charge of the SEM. During this time, the two SEM divisions "asylum" and "return" were merged. This meant that caseworkers had to do everything from interviewing asylum seekers, to taking decisions, to organising so-called "voluntary returns" (see Loher 2020) and deportations, including, at times, being present for the deportations. While some decision-makers said they valued this time for the new perspectives it gave them on their job, most decision-makers said that, in retrospect, they did not enjoy doing their job during those three years. Whether having to carry out all these tasks had an impact on the officials' decision-making and the outcome of their decisions I do not know. However, based on the office gossip I heard, it can be assumed that following decisions through to the end in this way does not necessarily lead to more lenient decision-making. Thus, several decision-makers told me that their colleagues from the return division were much stricter and, if it were up to them "would send everybody back". ${ }^{19}$ Working together with them had, therefore, been quite challenging.

In their work, SEM officials are confronted with stories of brutal and traumatising experiences and endured hardships on a daily basis. Furthermore, they are aware of the potential consequences their decisions might have for asylum seekers. Psychological distancing, in this regard, functions as an important coping mechanism. Psychological distancing mainly works through the shifting of responsibility. In Chapter 4, I showed how through rejecting asylum claims on the basis of non-credibility, the responsibility for the outcome of the decisions is shifted to the asylum seekers themselves: it is their fault for not telling the truth. Moreover, responsibility is shifted to "the law" (see also Jubany 2017: 210). Hence, decision-makers often explained to me that they had no choice but to take a certain decision in the 'cases' they were working on because that was what "the law" required. In this regard, one decision-maker told me that when people who had "no reasons for being granted asylum at all" asked him why he would not help them, he sometimes explained it like this: "Look, it's like you've just come into a TV shop and I'm the shop assistant. You come into the shop and ask for a broom, but all I have here are TVs. I have no brooms I could give you. You want a

${ }^{19}$ Kristina, caseworker, headquarters, field notes, my own translation. 
broom and I only have TVs". ${ }^{20}$ Finally, and in connection with the above, in my conversations with decision-makers the latter occasionally also shifted the responsibility to politicians and the electorate, since, in their view, it was ultimately the politicians and the electorate that make asylum law and politics. They were the ones who had turned asylum law into what it was today.

Nevertheless, despite responsibility being to some extent shifted to others in this way, this does not mean that the caseworkers do not also assume responsibility for their decisions. In fact, this responsibility "of actually making a difference" is one of the things several of the decision-makers said they liked best about their job. Assuming responsibility for the outcome of one's decisions is seen as a virtue and regarded as a necessity for good decision-making. Hence, it is something of a credo in the SEM that, as a decision-maker, one must always be able to stand by one's decisions. Not only this, but also as caseworker Alexandra put it:

Principally one has to ask oneself: If I took a negative decision, if I decided that this person has to go home again, would I be capable of accompanying this person home. And if you say, phew, I'd have scruples doing that, looking a person in the eye and saying: "You have to go home", then in difficult cases this might "tip the balance" (das Zünglein an der Waage spielen). ${ }^{21}$

What Alexandra is referring to here is the granting of temporary admission in the case that asylum has been denied. The question decision-makers must then decide upon is whether the person should be allowed to stay in Switzerland or not, which, in the latter case, might lead to the person being deported. I regularly observed that such decisions are not easy ones for caseworkers to take. Hence, they like it when there are "clear standards" they can measure their 'cases' against: for instance, if the APPAs explicitly define areas that are "safe", meaning that people can be sent back to them, and such that are not; or if they lay out clear criteria applicants from a certain country or region must fulfil in order to be eligible for subsidiary protection. But even so such decisions often remain difficult. The 'case' of the Iraqi family constituted a difficult case for Rebecca-and it had "tipped the balance" for her. For Alberto it had not, which had to do with his understanding of fairness, as I will discuss in more detail below. I do not know what decision Rebecca finally ended up taking because I left her asylum unit soon after the encounter with her and Alberto. Maybe she tried finding "better arguments" in order to convince Alberto that her decision was "the right one" after all. However,

\footnotetext{
${ }^{20}$ Nick, caseworker, headquarters, interview transcript, my own translation.

${ }^{21}$ Alexandra, caseworker, reception and processing centre, interview transcript, my own translation.
} 
from the conversation I observed, it seemed more likely that Rebecca would re-write the last part of her decision completely, providing justification for why sending the family back to Iraq was both permitted under international law and reasonable in humanitarian terms. ${ }^{22}$

\section{The Sufficiently but Not Overly Suspicious Decision-Maker}

A very important professional norm in the SEM is "suspicion" or nonnaivety. To be sufficiently suspicious is regarded as "a sign of professionalism" (Alpes and Spire 2014: 269). Conversely, "naively" believing asylum seekers' statements without properly testing their credibility is regarded as a sign of unprofessionalism, as Alberto insinuates in the field anecdote described above (see also Miaz 2017a: 347). The same has also been described for other administrations where people make (rights) claims on the state (Borrelli et al., forthcoming), such as French consulates (Alpes and Spire 2014: 269; Spire 2008), German asylum administrations (Scheffer 2003: 456), Swiss registry offices (Lavanchy 2014) and welfare offices in the USA (Watkins-Hayes 2009: 50-51).

The norm of "suspicion" is linked to decision-makers' self-understanding as protectors of the system. In other words, it is connected to the ethics of the office.

Many asylum seekers cannot be classified as refugees or persons displaced by war. On the basis of their situation, they clearly belong to the group of migrants. They are in search of a better place to live in Switzerland. [...] Many of them invent a dramatic story of persecution for the hearing by the authorities. With such tactics they hope to be granted refugee status. [...] The authorities must reject such applications without delay and execute removal systematically. ${ }^{23}$

The quote from the SEM website shows that the common assumption is that most asylum seekers are "bogus", that they belong to the so-called group of "economic migrants" and are trying to manipulate the system in order

\footnotetext{
${ }^{22}$ I would like to remind the reader that the family was not actually from Iraq, so no conclusions should be drawn regarding the SEM's practice in connection to different countries. For reasons of anonymity I have changed several identity markers of 'cases' so that the officials dealing with them remain anonymous and can, to the best of my knowledge, not be identified by their co-workers and superiors.

${ }^{23}$ https://perma.cc/ZG4B-NN6U, last accessed 26.02.2020.
} 
to be able to stay (see also Kelly 2012: 755; Souter 2011: 48). It is therefore the decision-makers' duty to combat "fraud", uncover the "undeserving" and reject their claims as quickly as possible. This understanding of asylum decision-making leads to "a shift from trying to find the truth to searching for untruth, from a concern with proof to a concern with lies" (Kelly 2012: 765). Or, put differently, it calls for suspicion. Hence, the way several caseworkers described their role-particularly in asylum interviews-to me was that of a "sceptic". They see it as their duty to ask as many questions as necessary until they are convinced that the asylum seeker's story is true, or to produce sufficient arguments for writing a negative decision (see Chapters 4 and 5).

Yet, while being sceptical is a sign of professionalism, being overly suspicious is regarded as a vice. Decision-makers who are said to enter asylum interviews with closed minds, always already knowing that everything will be a lie, are criticised by their colleagues for doing their job badly. They are called "cynics" by their critics. This "cynical" attitude to decision-making opposes the professional norm of open-mindedness. Hence, during my research, I was frequently told what is also taught in the training modules; that decisionmakers must be open-minded in order to do their job well. They should go into every interview with a tabula rasa even if, at the same time, they should already have an idea of what the decision might be in order to conduct the interview efficiently.

Becoming a cynic is perceived as a greater risk for older employees who have already "seen too much". Naivety, in turn, is mostly attributed to new decision-makers. It is seen as something newcomers have to grow out of. They first have to learn to become sceptical enough and dig deep enough in asylum interviews. Accordingly, as a sort of newcomer myself, I was also perceived as being naïve and believing asylum seekers "too readily". Connected to these perceptions is a crucial difference in critique. Whereas naïve decision-making is regularly equated with being unprofessional, I have never come across the same criticism for cynical decision-making. ${ }^{24}$ New decision-makers who "naïvely believe everything the claimants tell them" appear to lack sufficient understanding of what it means to properly fulfil their duty, and experienced decision-makers who naïvely believe an applicant are often criticised as being lazy_too lazy, one could interpret, to properly fulfil their duties. On the other hand, the term often used to describe an overly suspicious and cynical attitude is déformation professionelle, or occupational hazard. Used by SEM officials to describe how the views of decision-makers may become distorted by long service on the job, this term is applied when veracity is disparaged

\footnotetext{
${ }^{24}$ And neither have Jonathan Miaz and Ephraim Poertner who also conducted research in the SEM (see Affolter et al. 2019: 281).
} 
too much. ${ }^{25}$ Thus, critiques of cynical decision-making do not criticise offcials for being unprofessional or not protecting the system, but for taking protection too far, and losing sight of those who are "deserving".

\section{Ethos Is Ethics: The Fair Decision-Maker}

Alberto tells me that for him it is very important that all the asylum decisions leaving his section are fair. That is why he does not want the Iraqi family to be granted temporary protection. For him, fairness is about reserving protection for those "truly deserving" of it. This view is also expressed by Gabriel, who once explained to me that it was the decision-makers' duty to meticulously examine the credibility of each case-and, thus, to be sufficiently suspicious-because otherwise "everybody could just receive asylum and that would be unfair to those who really deserve asylum, who really need protection". ${ }^{26}$

Fairness is something that comes up a lot in my ethnographic material. As a procedural norm it means treating equal things equally and unequal things unequally. Hence, it stands for legal equality. However, the way this procedural norm is interpreted in the SEM "indicates that more is at stake than concerns about pure procedure" as David Loher has shown for so-called "return migration bureaucrats" in Switzerland (2020: 122). For SEM officials, taking fair decisions means using "the same standards for evaluating each claim". ${ }^{27}$ Ideally, they said, it should not matter who decides a particular case, the outcome should always be the same. The way to achieve this is for them is to strictly follow the law as well as the rules set out by institutional practice. Hence, strict rule-following is crucial in this regard.

For SEM officials, strict rule-following or application of the law is understood in this sense: if there are legal arguments for rejecting a case, it must be rejected. One should not grant asylum or temporary protection in such cases just because making a positive decision might be quicker than meticulously arguing a negative decision, because one has become emotionally attached to the applicant, or because of personal political opinions, for example. At the same time, if there are clearly no justifications for rejecting a claim, reasons

\footnotetext{
${ }^{25}$ In academia, the term deformation professionelle can be traced back to the sociologist Daniel Warnotte, who used it to describe how "bureaucrats" become "intellectually and emotionally damaged by their roles" (Maccoby 2007: 62).

${ }^{26}$ Gabriel, caseworker, headquarters, interview transcript, my own translation.

${ }^{27}$ Nora, head of asylum unit, headquarters, field notes, my own translation.
} 
should not be made up out of thin air. That too would be considered unfair. Fairness and strict rule-following, therefore, subsume and build on many other professional values: apolitical-ness, emotional detachment, professional suspicion, objectivity and non-cynicism.

Furthermore, they are connected to the ethics of the office. Or as Julia Eckert by drawing on David Loher (2020) claims, in this case, because fairness is equated with strict rule-following which, in turn, is understood in the above-discussed way, "ethos is ethics" (2020: 21). Fittingly, in the SEM, good decision-makers are those who in the name of fairness properly fulfil their duty of digging deep in every 'case' in order to make sure that there are "truly no reasons" for rejection. Consequently, decision-makers who take justice into their own hands by trying to help someone who is "undeserving" are portrayed as behaving in an unfair and unprofessional manner. Thus, one caseworker, Lucy, once explained to me that trying to help an "undeserving" applicant-even someone who had suffered great injustice, for example, by being "so poor he could not feed his five kids"-would be unfair to others because:

This can rapidly lead to one marching to a different drum. And in my opinion, then you are not being fair anymore, even though you want to be. Because your decisions don't conform with our asylum practice, you're not maintaining a unité de doctrine. [...] It is not up to us to decide what is just or not. [...]. Really, it's the politician who should ask himself that question. ${ }^{28}$

As we see, Lucy fears that by "over-generously" helping one person she might end up being "unfair" towards other (more "deserving") asylum seekers. This view was shared by many of my interaction partners. The world is an unjust place, several of them offered in explanation, but it was not up to them to change that. Justice, they felt, was the responsibility of politics and politicians (see also Liodden 2016: 208). ${ }^{29}$ Their duty, in turn, is to protect the system. That is what fairness means.

\footnotetext{
${ }^{28}$ Lucy, caseworker, headquarters, interview transcript, my own translation.

${ }^{29}$ This fits with what Veena Das argues when she writes that "detachment is done by an explicit distancing from the political process, taking it as a given for the particular outcomes to be produced" (2015: 104).
} 


\section{Conclusion}

This chapter has dealt with what decision-makers think they should do. This is important because, as Julia Eckert (2020) has argued, what administrative caseworkers think they should do shapes what they do. What decision-makers do again leads to the creation of certain (legal) truths. Hence, for instance, if a decision-maker in-line with the professional norm of suspicion-and in the name of fairness-digs deep, thereby creating the contradictions needed to reason a negative decision on the basis of non-credibility, a particular figure of the "false refugee" is created. And once asylum seekers have been classified as "false refugees" by assigning them to the legal category of "non-refugee", their existence becomes a fact, leading to and reinforcing the perception that, indeed, there "are" many false refugees which, in turn, strengthens the office's and individual decision-makers' endeavours to identify and exclude them from asylum (see also Zimmermann 2011: 337). At the same time, if after digging deep the decision-maker reaches the conclusion that there are no (or not enough) reasons for disbelieving an applicant, a certain image of the "genuine refugee" — of a person "deserving of protection"—is (re-)produced.

What decision-makers do is structured not only by procedural normsthe ethos of the office-but also by the broader ideological environment the administration is embedded in. The ideological environment is expressed through the ethics of the office. It is not, however, without contradictions. Decision-makers in the SEM embody the role of protectors of the system. It is their duty to "help people" (in the name of Switzerland, so to say). At the same time, they must make sure Switzerland fulfils its humanitarian duty. They must protect the abstract, noble value of asylum and they must protect the asylum system from being abused. Sometimes these duties were reflexively made explicit by decision-makers when explaining their job to me. But more often they came out of decision-makers retrospectively justifying their actions, and out of their assessments of co-workers' practices. Furthermore, decision-makers' role as protectors of the system can be discerned from what they do in practice. Therefore, I argue that this role constitutes part of officials' implicit professional identity. In this way, it shapes what decisionmakers do, generating certain "truths" and thereby (re-)producing the norms and values at the heart of their everyday work.

Much concern in street-level bureaucracy literature is with the dilemma caseworkers experience between caring for people, wanting to help them and becoming personally involved in their 'cases', on the one hand, and their duty to follow the rules, on the other (see Lipsky 2010). Other authors working on bureaucratic administrations are less concerned with this dilemma but 
rather argue that caseworkers' concern and compassion for the people they deal with is overridden by other concerns: most notably instrumental-rational rule-following (Gill 2016: 136; see also Arendt 2013; Bauman 1988, 1989; Herzfeld 1992). My take on this, which derives from this chapter, is a different one. I do not wish to claim that SEM officials never struggle with the dilemma between "compassion and flexibility on the one hand, and impartiality and rigid rule-application on the other hand" (Lipsky 2010: 15-16). Nor do I argue that decision-makers never act indifferently towards asylum seekers. However, an observation I made was that mostly, decision-makers care about the people they deal with. Yet, this compassion for people is not necessarily perceived as the opposite pole of strict rule-following. For decision-makers, it is the morally and ethically right thing to reserve protection for those "truly in need and deserving" of it—and to limit it to them. In this sense, compassion and strict rule-following are brought together in the name of fairness. For understanding what administrative caseworkers do we should, therefore, not only pay attention to the dilemmas they experience, but also to how they overcome such dilemmas and why they might not experience certain dilemmas we-from the outside—expect them to.

\section{References}

Affolter, Laura, Jonathan Miaz, and Ephraim Poertner. 2019. "Taking the 'Just' Decision: Caseworkers and Their Communities of Interpretation in the Swiss Asylum Office." In Asylum Determination in Europe: Ethnographic Perspectives, edited by Nick Gill, and Anthony Good, 263-284. Cham: Palgrave Macmillan. Alpes, Maybritt Jill, and Alexis Spire. 2014. "Dealing with Law in Migration Control: The Powers of Street-Level Bureaucrats at French Consulates." Social \& Legal Studies 23 (2): 261-274. https://journals.sagepub.com/doi/10.1177/096 4663913510927.

Arendt, Hannah. 2013. Eichmann in Jerusalem: Ein Bericht von der Banalität des Bösen. München: Piper.

Bauman, Zygmunt. 1988. "Sociology after the Holocaust." The British Journal of Sociology 39 (4): 469-497. https://doi.org/10.2307/590497.

Bauman, Zygmunt. 1989. Modernity and the Holocaust. Cambridge: Polity Press.

Bohmer, Carol, and Amy Shuman. 2008. Rejecting Refugees: Political Asylum in the 21st Century. London: Routledge.

Bohmer, Carol, and Amy Shuman. 2018. Political Asylum Deceptions: The Culture of Suspicion. Cham: Palgrave Macmillan.

Borrelli, Lisa Marie, Annika Lindberg, and Anna Wyss. Forthcoming. "States of Suspicion: How Institutionalised Disbelief Shapes Migration Control Regimes." Geopolitics. 
Cabot, Heath. 2013. "The Social Aesthetics of Eligibility: NGO Aid and Indeterminacy in the Greek Asylum Process." American Ethnologist 40 (3): 452-466. https://doi.org/10.1111/amet.12032.

Candea, Matei, Joanna Cook, Catherine Trundle, and Thomas Yarrow. 2015. "Introduction: Reconsidering Detachment." In Detachment: Essays on the Limits of Relational Thinking, edited by Matei Candea, Joanna Cook, Catherine Trundle, and Thomas Yarrow, 1-25. Manchester: Manchester University Press.

Dahlvik, Julia. 2018. Inside Asylum Bureaucracy: Organizing Refugee Status Determination in Austria. IMISCOE Research Series. Cham: Springer.

Das, Veena. 2015. "Professionalism and Expertise: Comment." In Detachment: Essays on the Limits of Relational Thinking, edited by Matei Candea, Joanna Cook, Catherine Trundle, and Thomas Yarrow, 102-111. Manchester: Manchester University Press.

Downs, Anthony. 1967. Inside Bureaucracy. Boston: Little, Brown and Company.

Dubois, Vicent. 2005. "L'insécurité juridique des contrôleurs des CAF: Une perspective sociologique." Informations sociales 126: 46-57.

Eckert, Julia. 2020. "The Office: Ethos and Ethics in Migration Bureaucracies." In The Bureaucratic Production of Difference, edited by Julia Eckert, 7-26. Bielefeld: transcript.

Eule, Tobias G. 2014. Inside Immigration Law: Migration Management and Policy Application in Germany. Farnham: Ashgate.

Fassin, Didier. 2007. "Humanitarianism as a Politics of Life." Public Culture 19 (3): 499-520. https://doi.org/10.1215/08992363-2007-007.

Fassin, Didier. 2012. Humanitarian Reason: A Moral History of the Present. Berkeley: University of California Press.

Fassin, Didier, and Carolina Kobelinsky. 2012. "How Asylum Claims Are Adjudicated: The Institution as a Moral Agent." Revue française de sociologie 53 (4): 444-472. https://doi.org/10.3917/rfs.534.0657.

Fresia, Marion, David Bozzini, and Alice Sala. 2013. "Les rouages de l'asile en Suisse: Regards ethnographiques sur une procédure administrative." Etudes du SFM 62. Neuchâtel: SFM.

Fuglerud, Oivind. 2004. "Constructing Exclusion: The Micro-Sociology of an Immigration Department.” Social Anthropology 12 (1): 25-40. https://doi.org/ 10.1111/j.1469-8676.2004.tb00088.x.

Gill, Nick. 2009. "Presentational State Power: Temporal and Spacial Influences over Asylum Sector Decisionmakers." Transactions of the Institute of British Geographers 34 (2): 215-233. https://doi.org/10.1111/j.1475-5661.2009.00337.x.

Gill, Nick. 2016. Nothing Personal: Geographies of Governing and Activism in the British Asylum System. Oxford: Wiley-Blackwell.

Graeber, David. 2015. The Utopia of Rules: On Technology, Stupidity, and the Secret Joys of Bureaucracy. Brooklyn and London: Melville House.

Herzfeld, Michael. 1992. The Social Production of Indifference: Exploring the Symbolic Roots of Western Bureaucracy. New York: Berg. 
Heyman, Josiah McC. 2009. "Trust, Privilege, and Discretion in the Governance of US Borderlands with Mexico." Canadian Journal of Law and Society 24 (3): 367-390. https://doi.org/10.1017/S0829320100010085.

Hood, Christopher. 1991. "A Public Management for All Seasons?" Public Administration 69 (1): 3-19. https://doi.org/10.1111/j.1467-9299.1991.tb00779.x.

Johannesson, Livia. 2017. In Courts We Trust: Administrative Justice in Swedish Migration Courts. Stockholm University. http://www.diva-portal.org/smash/get/ diva2:1072557/FULLTEXT01.pdf, last accessed February 3, 2020.

Jubany, Olga. 2017. Screening Asylum in a Culture of Disbelief: Truths, Denials and Sceptical Borders. Cham: Palgrave Macmillan.

Kelly, Tobias. 2012. "Sympathy and Suspicion: Torture, Asylum, and Humanity." Journal of the Royal Anthropological Institute 18 (4): 753-768. https://doi.org/10. 1111/j.1467-9655.2012.01790.x.

Kobelinsky, Carolina. 2015. "In Search of Truth: How Asylum Applications Are Adjudicated." In At the Heart of the State: The Moral World of Institutions, edited by Didier Fassin, 67-92. London: Pluto Press.

Lavanchy, Anne. 2013. "L'amour aux services de l'état civil: régulations institutionnelles de l'intimité et fabrique de la ressemblance nationale en Suisse." Migrations Société 150: 61-77.

Lavanchy, Anne. 2014. "Die Gefühlswelt des Gesetzes. Die kritische Umsetzung von eherechtlichen Vorschriften im Zivistandsamt." FAMPRA 1: 92-117.

Lentz, Carola. 2014. "I Take an Oath to the State, Not the Government': Career Trajectories and Professional Ethics of Ghanaian Public Servants." In States at Work: Dynamics of African Bureaucracies, edited by Thomas Bierschenk, and JeanPierre Olivier de Sardan, 175-204. Leiden and Boston: Brill.

Liodden, Tone Maia. 2016. "The Burdens of Discretion: Managing Uncertainty in the Asylum Bureaucracy." PhD diss. (unpublished), University of Oslo.

Lipsky, Michael. 2010. Street-Level Bureaucracy, 30th Anniversary Edition: Dilemmas of the Individual in Public Service. New York: Russell Sage Foundation.

Loher, David. 2020. "Governing the Boundaries of the Commonwealth: The Case of So-Called Assisted Voluntary Return Migration." In The Bureaucratic Production of Difference, edited by Julia Eckert, 113-134. Bielefeld: transcript.

Maccoby, Michael. 2007. The Leaders We Need: And What Makes Us Follow. Boston: Harvard Business School Press.

Miaz, Jonathan. 2017a. "Politique d'asile et sophistication du droit: Pratiques administratives et défense juridique des migrants en Suisse (1981-2015)." PhD diss. (unpublished), University of Lausanne and University of Strasbourg.

Miaz, Jonathan. 2017b. "From the Law to the Decision: The Social and Legal Conditions of Asylum Adjudication in Switzerland." European Policy Analysis 3 (2): 372-396. https://doi.org/10.1002/epa2.1018.

Poertner, Ephraim. 2017. "Governing Asylum through Configurations of Productivity and Deterrence: Effects on the Spatiotemporal Trajectories of Cases in Switzerland." Geoforum 78: 12-21. https://doi.org/10.1016/j.geoforum.2016. 11.004. 
Poertner, Ephraim. 2018. "Re-Cording Lives: Governing Asylum in Switzerland and the Need to Resolve.” PhD diss. (unpublished), University of Zurich.

Probst, Johanna. 2012. Instruire la demande d'asile: étude comparative du processus décisionnel au sein de l'administration allemande et française. Science politique, Université de Strasbourg. https://tel.archives-ouvertes.fr/tel-00985215/doc ument, last accessed February 3, 2020.

Rose, Nikolas. 1999. Powers of Freedom: Reframing Political Thought. Cambridge: Cambridge University Press.

Scheffer, Thomas. 2001. Asylgewährung: Eine ethnographische Analyse des deutschen Asylverfahrens. Stuttgart: Lucius \& Lucius.

Scheffer, Thomas. 2003. "Kritik der Urteilskraft: Wie die Asylprüfung Unentscheidbares in Entscheidbares überführt." In Migration steuern und verwalten: Deutschland vom späten 19. Jahrhundert bis zur Gegenwart, edited by Jochen Oltmer, 423-458. Göttingen: Vandenhoeck \& Ruprecht.

Shore, Cris, and Susan Wright. 1997. "Introduction: Policy: A New Field of Anthropology." In Anthropology of Policy: Critical Perspectives on Governance and Power, edited by Cris Shore, and Susan Wright, 3-30. London and New York: Routledge.

Silbey, Susan S. 2005. "After Legal Consciousness." Annual Review of Law and Social Science 1: 323-368. https://doi.org/10.1146/annurev.lawsocsci.1.041604. 115938.

Souter, James. 2011. "A Culture of Disbelief or Denial? Critiquing Refugee Status Determination in the United Kingdom." Oxford Monitor of Forced Migration 1 (1): 48-59.

Spire, Alexis. 2008. Accueillir ou reconduire: enquête sur les guichets de l'immigration. Paris: Raisons d'agir.

Ticktin, Miriam. 2006. "Where Ethics and Politics Meet: The Violence of Humanitarianism in France." American Ethnologist 33 (1): 33-49. https://doi.org/10. 1525/ae.2006.33.1.33.

Watkins-Hayes, Celeste. 2009. The New Welfare Bureaucrats: Entanglements of Race, Class, and Policy Reform. Chicago: University of Chicago Press.

Weber, Max. 1991 (1948). From Max Weber: Essays in Sociology. Translated, edited and with an introduction by Hans H. Gerth, and C. Wright Mills. London and New York: Routledge and Kegan Paul.

Weber, Max. 2013 (1978). Economy and Society. Edited by Guenther Roth, and Claus Wittich. Berkeley: University of California Press.

Wedel, Janine R., Cris Shore, Gregory Feldman, and Stacey Lathrop. 2005. “Toward an Anthropology of Public Policy." Annals of the American Academy of Political and Social Science 600 (1): 30-51. https://doi.org/10.1177/0002716205276734.

Zetter, Roger. 2007. "More Labels, Fewer Refugees: Remaking the Refugee Label in an Era of Globalization.” Journal of Refugee Studies 20 (2): 172-192. https://doi. org/10.1093/jrs/fem011. 
Zimmermann, Susan E. 2011. "Reconsidering the Problem of 'Bogus' Refugees with 'Socio-economic Motivations' for Seeking Asylum.” Mobilities 6: 335-352. https://doi.org/10.1080/17450101.2011.590034.

Open Access This chapter is licensed under the terms of the Creative Commons Attribution 4.0 International License (http://creativecommons.org/licenses/by/4.0/), which permits use, sharing, adaptation, distribution and reproduction in any medium or format, as long as you give appropriate credit to the original author(s) and the source, provide a link to the Creative Commons license and indicate if changes were made.

The images or other third party material in this chapter are included in the chapter's Creative Commons license, unless indicated otherwise in a credit line to the material. If material is not included in the chapter's Creative Commons license and your intended use is not permitted by statutory regulation or exceeds the permitted use, you will need to obtain permission directly from the copyright holder.

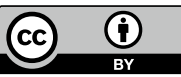

